\title{
GUIDELINES TO AUTHORS
}

1. Papers for publication should be sent in quadruplicate to one of the Editors:

Hans Bühlmann,

Mathematik, ETH-Zentrum,

CH-8092 Zürich, Switzerland.

or to one of the Co-Editors:

Alois Gisler,

"Winterthur" Swiss Insurance Company,

P.O. Box 357, CH-8401 Winterthur, Switzerland.

David Wilkie

Messrs. R. Watson \& Sons

Watson House, London Rd., Reigate, Surrey RH2 9PQ, United Kingdom.

Submission of a paper is held to imply that it contains original unpublished work and is not being submitted for publication elsewhere.

Receipt of the paper will be confirmed and followed by a refereeing process, which will take about three months.

2. Manuscripts should be typewritten on one side of the paper, double-spaced with wide margins. The basic elements of the journal's style have been agreed by the Editors and Publishers and should be clear from checking a recent issue of ASTIN BULLETIN. If variations are felt necessary they should be clearly indicated on the manuscript.

3. Papers should be written in English or in French. Authors intending to submit longer papers (e.g. exceeding 30 pages) are advised to consider splitting their contribution into two or more shorter contributions.

4. The first page of each paper should start with the title, the name(s) of the author(s), and an abstract of the paper as well as some major keywords. An institutional affiliation can be placed between the name(s) of the author(s) and the abstract.

5. Footnotes should be avoided as far as possible.

6. Upon acceptance of a paper, any figures should be drawn in black ink on white paper in a form suitable for photographic reproduction with lettering of uniform size and sufficiently large to be legible when reduced to the final size.

7. References should be arranged alphabetically, and for the same author chronologically. Use a, b, c, etc. to separate publications of the same author in the same year. For journal references give author(s), year, title, journal (in italics, cf. point 9), volume (in boldface, cf. point 9), and pages. For book references give author(s), year, title (in italics), publisher, and city.

Examples:

Barlow, R.E. and Proschan, F. (1975) Mathematical Theory of Reliability and Life Testing. Holt, Rinehart, and Winston, New York.

JEWELL, W.S. (1975a) Model variations in credibility theory. In Credibility: Theory and Applications (ed. P. M. KAHN), pp. 193-244, Academic Press, New York.

JEWELL, W.S. (1975b) Regularity conditions for exact credibility. ASTIN Bulletin 8, 336-341.

References in the text are given by the author's name followed by the year of publication (and possibly a letter) in parentheses.

8. The address of at least one of the authors should be typed following the references.

Continued overleaf. 


\section{COMMITTEE OF ASTIN}

$\begin{array}{lll}\text { James N. STANARD } & \text { USA } & \text { Chairman } \\ \text { Jukka RANTALA } & \text { Finland } & \text { Vice-Chairman } \\ \text { Bouke POSTHUMA } & \text { Netherlands } & \text { Secretary } \\ \text { Jean LEMAIRE } & \text { Belgium/USA } & \text { Treasurer } \\ \text { Hans BÜHLMANN } & \text { Switzerland } & \text { Editor/IAA-Delegate } \\ \text { D. Harry REID } & \text { United Kingdom } & \text { Editor } \\ \text { James MACGINNITIE } & \text { USA } & \text { Member/IAA-Delegate } \\ \text { Björn AJNE } & \text { Sweden } & \text { Member } \\ \text { Edward J. LEVAY } & \text { Israel } & \text { Member } \\ \text { Charles LEVI } & \text { France } & \text { Member } \\ \text { Thomas MACK } & \text { Germany } & \text { Member } \\ \text { Ermanno PITACCO } & \text { Italy } & \text { Member } \\ \text { Gregory C. TAYLOR } & \text { Australia } & \text { Member } \\ \text { Alois GISLER } & \text { Switzerland } & \text { Co-Editor } \\ \text { David WILKIE } & \text { United Kingdom } & \text { Co-Editor }\end{array}$

Neither the COMMITTEE of ASTIN nor CeUTERICK s.a. are responsible for statements made or opinions expressed in the articles, criticisms and discussions published in ASTIN BULLETIN.

Guidelines to Authors continued from inside back cover.

9. Italics (boldface) should be indicated by single (wavy) underlining. Mathematical symbols will automatically be set in italics, and need not be underlined unless there is a possibility of misinterpretation.

Information helping to avoid misinterpretation may be listed on a separate sheet entitled 'special instructions to the printer'. (Example of such an instruction: Greek letters are indicated with green and script letters with brown underlining, using double underlining for capitals and single underlining for lower case.)

10. Electronic Typesetting using Word Perfect 5.1 is available. Authors who wish to use this possibility should ask one of the editors for detailed instructions.

11. Authors will receive from the publisher two sets of page proofs together with the manuscript. One corrected set of proofs plus the manuscript should be returned to the publisher within one week. Authors may be charged for alterations to the original manuscript.

12. Authors will receive 50 offprints free of charge. Additional offprints may be ordered when returning corrected proofs. A scale of charges will be enclosed when the proofs are sent out. 